\title{
R8 Padronização da reação em cadeia da polimerase quantitativa em tempo real na detecção do DNA de Leishmania
}

Diego Lima Candido da Silva¹, Otávio de Melo Espíndola¹, Aline Fagundes da Silva ${ }^{1}$

${ }^{1}$ Instituto Nacional de Infectologia, Fiocruz, Rio de Janeiro, RJ

Introdução: O diagnóstico de certeza para leishmaniose tegumentar é realizado através da observação do parasito no material obtido das lesões sugestivas. O resultado favorável do diagnóstico depende de fatores como a espécie de parasito, a forma clinica e o tempo de evolução da doença e outras variáveis. Ainda são poucos os trabalhos utilizando a quantificação de ácidos nucléicos de Leishmania em diagnóstico, no entanto, a padronização dessa ferramenta poderia ser útil na obtenção da melhoria da eficiência do diagnóstico e da caracterização clinica e epidemiológica da doença.

Objetivo: Padronizar a q-PCR para Leishmania, incluindo as etapas de titulação dos iniciadores da reação; construção da curva padrão com DNA de cepa referência de Leishmania e determinação da faixa de detecção da q-PCR.

Metodologia: A q-PCR foi realizada utilizando-se os iniciadores direcionados à região conservada do DNA do cinetoplasto de Leishmania, com o kit ROTOR- GENE® SYBR GREEN (Quiagen®). A ciclagem consistiu de um estágio de 5 segundos a $95^{\circ} \mathrm{C}$, e $30-40$ ciclos de 15 segundos a $60^{\circ} \mathrm{C}$. Uma curva de dissociação foi realizada para cada reação, para identificação dos produtos amplificados. A reação foi realizada em $25 \mu \mathrm{L}$ de solução contendo $5 \mu \mathrm{L}$ de DNA alvo, 12,5 $\mu \mathrm{L}$ PCR master mix (do kit Rotor Gene $\AA$ ), água milli $Q$ e os iniciadores, titulados para padronização da melhor concentração. Para avaliação da reação, foram realizadas curvas padrão, utilizando DNA de cepa referência de L. (V.) braziliensis e L.(L)amazonensis, em 5 concentrações conhecidas. A determinação da faixa de detecção da reação por meio de curva de titulação de DNA alvo extraído de promastigotas de cepa referência de Leishmania (V.) braziliensis. O software integrado ao sistema ROTOR GENE possibilita a análise computadorizada dos resultados.

Resultados: As seguintes concentrações de iniciadores foram utilizadas na detecção de DNA das culturas (HM1- 15 pMol / $\mu \mathrm{L} ; \mathrm{HM} 2$ $30 \mathrm{pMol} / \mu \mathrm{L}$ e HM3- $15 \mathrm{pMol} / \mu \mathrm{L}$ ). Com essas concentrações todas as amostras de cultura amplificaram, demonstrando o reconhecimento das espécies de Leishmania mais importantes do Brasil. A curva de dissociação da reação acima mostrou que as espécies puderam ser identificadas. Para a curva de titulação, foram utilizadas diluições seriadas de base 10 variando de 0,07 a $0.00000007 \mathrm{nG} / \mu \mathrm{L}$. Na diluição de $0.00000007 \mathrm{nG} / \mu \mathrm{L}$ foi observado um pico de dissociação 
inespecífico na curva de dissociação, compatível com o pico observado nos controles negativos. Assim sendo, a diluição anterior foi considerada o limiar de detecção da metodologia, a saber 0.0000007 $\mathrm{nG} / \mu \mathrm{L}$.

Conclusão: A metodologia de q-PCR padronizada neste trabalho detectou, quantificou e identificou DNA de diferentes espécies de Leishmania, com limiar de detecção de $0.0000007 \mathrm{nG} / \mu \mathrm{L}$. A partir da reação padronizada, poderão ser realizados ensaios para a determinação da sensibilidade diagnóstica do ensaio e do seu potencial para utilização em diagnóstico clinico.

Palavras-Chave: Leishmanioses, q-PCR, Diagnóstico 